\title{
Calcium paradox and calcium entry blockers
}

T.J.C. Ruigrok, A.M. Slade, W.G.Nayler and F.L. Meijler

\section{Summary}

Reperfusion of isolated hearts with calcium-containing solution after a short period of calcium-free perfusion results in irreversible cell damage (calcium paradox). This phenomenon is characterized by an excessive influx of calcium into the cells, the rapid onset of myocardial contracture, exhaustion of tissue high-energy phosphates, massive release of cell constituents, and extensive ultrastructural damage. The calcium paradox can be regarded as the most severe form of myocardial necrosis that can be produced experimentally.

Under the experimental conditions described in this study, the calcium entry blockers verapamil, nifedipine, dittiazem and lidoflazine failed to reduce the massive release of enzymes that occurs in the severe form of the calcium paradox. Calcium entry blockers, however, may alter the time course of the events that occur during the development of the calcium paradox.

Calcium entry blockers may have a protective effect in a mild form of the calcium paradox. This is of interest for cardiac surgery where calcium-free cardioplegic solutions are widely used. Calcium entry blockers may decrease the potential hazard of the use of these solutions. 


\section{Résumé}

Une reperfusion des coeurs isolés au moyen d'une solution contenant du calcium après une courte période de perfusion exempte de calcium entraîne une détérioration irréversible de la cellule (paradoxe de calcium). Ce phénomène est caractérisé par une pénétration excessive de calcium à l'intérieur des cellules, l'apparition d'une contracture myocardique, l'épuisement des phosphates tissulaires à haute énergie, une libération massive de constituants cellulaires et une détérioration ultrastructurale étendue. On peut considérer le paradoxe de calcium comme étant la manifestation la plus sévère de la nécrose myocardique susceptible de se produire sur le plan expérimental.

Dans les conditions expérimentales décrites dans cette étude, les bloqueurs de l'entrée de calcium vérapamil, nifédipine, dittiazem et lidoflazine ont échoué à réduire la libération massive des enzymes se produisant sous la forme sévère du paradoxe de calcium.

Les bloqueurs de l'entrée de calcium ont un effet protecteur dans la manifestation modérée du paradoxe de calcium. Ceci est important pour la chirurgie cardiaque pour laquelle des solutions cardioplégiques exemptes de calcium sont utilisées. Les bloqueurs de l'entrée de calcium peuvent diminuer le hasard potentiel de l'utilisation de ces solutions.

\section{Resumen}

La reperfusión de corazones aislados con una solución de concentración normal de calcio, después de un breve período de perfusión sin calcio, produce un perjuicio irremediable de la célula (paradoja del calcio). Este fenómeno se caracteriza por una penetración excesiva de calcio en las células, una aparición rápida de una contractura miocardiaca, un agotamiento de los fosfatos de alta energía en el tejido, una liberación masiva de componentes celulares y un notable perjuicio ultra-estructural. La paradoja del calcio puede ser considerada como la forma más severa de necrosis miocardíaca que puede producirse experimentalmente.

Bajo las condiciones experimentales descritas en este estudio, los inhibidores de la penetración intracelular de calcio verapamilo, nifedipino, dittiazem y lidoflazina no lograron disminuir el masivo escape de enzimas que ocurre en la forma severa de la paradoja del calcio. Estos inhibidores, sin embargo, pueden moderar los acontecimientos que ocurren durante el desarrollo de la paradoja del calcio y pueden tener un efecto protector en forma ligera contra la paradoja del calcio.

Esto es de interés para la cirugia cardíaca en la cual se usan frecuentemente soluciones cardioplégicas sin calcio. Los inhibidores de la penetración intracelular pueden disminuir los riesgos potenciales del uso de estas soluciones.

\section{Zusammenfassung}

Werden isolierte Herzen nach einer kurzen Periode kalziumfreier Perfusion von einer kalziumhaltigen Lösung durchströmt, so entstehen irreversible Zellschäden. Bei diesem Phänomen sind ein übermässiger Kalziumeinstrom in die Zellen, ein schnelles Einsetzen der Myokardkontraktion, eine Erschöpfung der energiereichen Gewebephosphate, ein massives Freiwerden von Zellbestandteilen, und umfangreiche ultrastrukturelle Schäden zu beobachten. Das Kalziumparadoxon kann als die schwerste Form experimentell hervorgerufener Myokardnekrose betrachtet werden.

Bei den hier beschriebenen experimentellen Umständen waren die Kalziumeintritthemmer Verapamil, Nifedipin, Diltiazem und Lidoflazin nicht imstande, die bei einer schweren Form des Kalziumparadoxon hervorgerufene massive Freisetzung von Enzymen zu vermindern. Sie können jedoch den Zeitverlauf der Ereignisse, die bei der Entwicklung des Kalziumparadoxon auftreten, beeinflussen.

Kalziumeintritthemmer können bei einer leichten Form des Kalziumparadoxon eine schützende Wirkung haben. Dies ist bei Herzchirurgie von Bedeutung, wo kalziumfreie Lösungen vielfach zur Kardioplegie gebraucht werden. Kalziumeintritthemmer können das mögliche Risiko einer Anwendung dieser Lösungen herabsetzen. 


\section{Introduction}

Coronary perfusion with a calcium-free solution results in the development of an electromechanical dissociation (Mines, 1913), but may in addition lead to an increase of the sarcolemmal permeability to calcium (Frank et al., 1977). As a consequence, reperfusion of the heart with calcium-containing solution results in a massive influx of calcium into the cells, followed by exhaustion of tissue high-energy phosphates, the rapid onset of myocardial contracture, massive release of cell constituents, and extensive ultrastructural damage (Zimmerman et al., 1967; Boink et al., 1976; Hearse et al., 1978). This phenomenon was first described by Zimmerman and Hülsmann (1966) and termed the calcium paradox.

In an attempt to reduce the damaging effect of sequential perfusion with calcium-free and calcium-containing medium, calcium entry blockers (verapamil, nifedipine, diltiazem or lidoflazine) were added to the perfusion fluids. Cell damage was quantitated in terms of enzyme leakage, depletion of high-energy phosphates, and ultrastructural damage.

\section{Materials and methods}

\section{Perfusion Technique}

Male Wistar rats of 200-250 g were anesthetized with diethyl ether. The rats were heparinized and the hearts quickly removed and subsequently perfused at $37^{\circ} \mathrm{C}$ by the Langendorff technique (1895) at a constant pressure of $10.0 \mathrm{kPa}(75 \mathrm{~mm} \mathrm{Hg})$. The standard perfusate had the following composition (mmol .1-1): $\mathrm{NaCl}, 124 ; \mathrm{KCl}, 4.7$; $\mathrm{CaCl}_{2}, 1.3 ; \mathrm{MgCl}_{2}, 1.0 ; \mathrm{NaHCO}_{3}, 24.0 ; \mathrm{Na}_{2} \mathrm{HPO}_{4}, 0.5 ;$ glucose, 11.0. During calciumfree perfusion, calcium was omitted from the standard medium; no correction was made for the small change of osmolarity. After equilibration of the perfusion fluids with $95 \% \mathrm{O}_{2} \cdot 5 \% \mathrm{CO}_{2}$, the $\mathrm{pH}$ was $7.40 \pm 0.05$.

After a 15 minute stabilization period, during which the hearts were perfused with calcium-containing standard medium, the perfusion was changed to the calcium-free solution. After 4 or 10 minutes of calcium-free perfusion, the hearts were reperfused with the calcium-containing solution. The concentration of the calcium entry blockers verapamil, nifedipine, diltiazem and lidoflazine in the perfusion fluids amounted to $1 \mathrm{mg}$ $.1^{-1}$.

\section{Analytical Procedures}

Samples of the effluent medium were collected and analyzed for creatine kinase (CK) activity. CK activity was assayed with the use of a Vitatron Automatic Kinetic Enzyme System (AKES) at $25^{\circ} \mathrm{C}$. Enzyme activity was expressed in IU released $.15 \mathrm{~min}^{-1} . \mathrm{g}^{-1}$ dry heart tissue $( \pm S D)$. 
The perfusion of hearts on which creatine phosphate (CP) and adenosine triphosphate (ATP) determinations were to be made, was terminated by freezing the hearts between large aluminium tongs, precooled in liquid nitrogen. The frozen tissue was assayed for CP and ATP as previously described (Boink et al., 1976). Myocardial CF and ATP content was expressed in $\mu \mathrm{mol} . \mathrm{g}^{-1}$ dry weight $( \pm \mathrm{SD})$.

The Student $t$ test was used in Table 1 and Figure 1 , taking $P=0.05$ as the limit of significance.

\section{Electron Microscopy}

Control hearts were perfused for 15 minutes with standard medium and then perfusion-fixed with $4 \%$ glutaraldehyde prepared in $0.2 \mathrm{~mol}^{.1-1}$ sodium cacodylate buffer $(\mathrm{pH}$ 7.3). Other hearts were perfused with calcium-free solution for 4 minutes, reperfused with calcium-containing solution for either 30 seconds or 30 minutes, with or without verapamil, and subsequently perfusion-fixed. After 10 minutes of glutaraldehyde perfusion, the hearts were removed from the Langendorff apparatus, and biopsy specimens of the left ventricle free wall were excised and cut into $1 \mathrm{~mm}^{3}$ cubes. These were immersion-fixed in the glutaraldehyde solution for 2 hours, then postfixed for 2 hours in $1 \% \mathrm{OsO}_{4}$. Samples were then stained en bloc with uranyl acetate, dehydrated and embedded in epoxy resin. Sections were examined in a Philips 301 electron microscope. Morphometric analysis of the micrographs was carried out as previously described (Ruigrok et al., 1980).

\section{Results}

\section{Effect of calcium entry blockers on the release of CK during reperfusion}

During the stabilization period and the subsequent 10 minute period of perfusion with calcium-free solution, the hearts released negligible amounts of CK into the coronary effluent. Reintroduction of calcium in the perfusion fluid resulted in massive release of CK (Table 1).

Table 1: Effect of verapamil, nifedipine, diltiazem, and lidoflazine $\left(1 \mathrm{mg} . \mathrm{l}^{-1}\right)$ on the calcium paradox in isolated rat hearts.

\begin{tabular}{|l|l|}
\hline Experiment & CK release $\left(\mathrm{IU} \cdot 15 \mathrm{~min}^{-1} \cdot \mathrm{g}^{-1}\right.$ dry wt) during reperfusion \\
\hline Untreated & $2065 \pm 250$ \\
Verapamil & $2135 \pm 185 \mathrm{NS}$ \\
Nifedipine & $2255 \pm 195 \mathrm{NS}$ \\
Diltiazem & $2270 \pm 160 \mathrm{NS}$ \\
Lidoflazine & $2265 \pm 70 \mathrm{NS}$ \\
\hline
\end{tabular}

The hearts were perfused for 15 minutes at $37^{\circ} \mathrm{C}$ with calcium-containing solution, followed by 10 minutes of calcium-free perfusion and 15 minutes of reperfusion with calcium-containing solution. In the treated hearts, the drug was present throughout the entire perfusion. Results are expressed as mean $\pm \mathrm{SD}(n=6)$. NS: not significantly different from the untreated hearts. 
The presence of verapamil, nifedipine, diltiazem or lidoflazine $(1 \mathrm{mg} \mathrm{.1-1})$ throughout the entire experiment had no significant effect on the calcium-induced release of $\mathrm{CK}$. Enzyme activity was measured in the coronary effluent collected during the first 15 minutes of reperfusion with calcium-containing solution.

In a previous investigation (Ruigrok et al., 1980) the effect of $1 \mathrm{mg} . .^{-1}$ verapamil, which was present during 4 minutes of calcium-free perfusion and the reperfusion phase, was studied. CK release was measured in samples of the coronary effluent collected during 30 seconds or 1 minute at timed intervals. The enzyme release pattern in the verapamil-treated hearts was not significantly different from that in the untreated hearts. In another study (Boink et al., 1980) it was shown that 4 minutes of calcium-free perfusion at $37^{\circ} \mathrm{C}$ was sufficient to obtain maximal $\mathrm{CK}$ release upon reperfusion with calcium-containing solution.

\section{Effect of verapamil on the depletion of tissue CP and ATP stores during reper- fusion}

At the end of the stabilization period myocardial CP and ATP stores amounted to $29.6 \pm 2.1$ and $18.8 \pm 0.8 \mu \mathrm{mol} \mathrm{g}^{-1}$ dry weight, respectively (Figure 1).

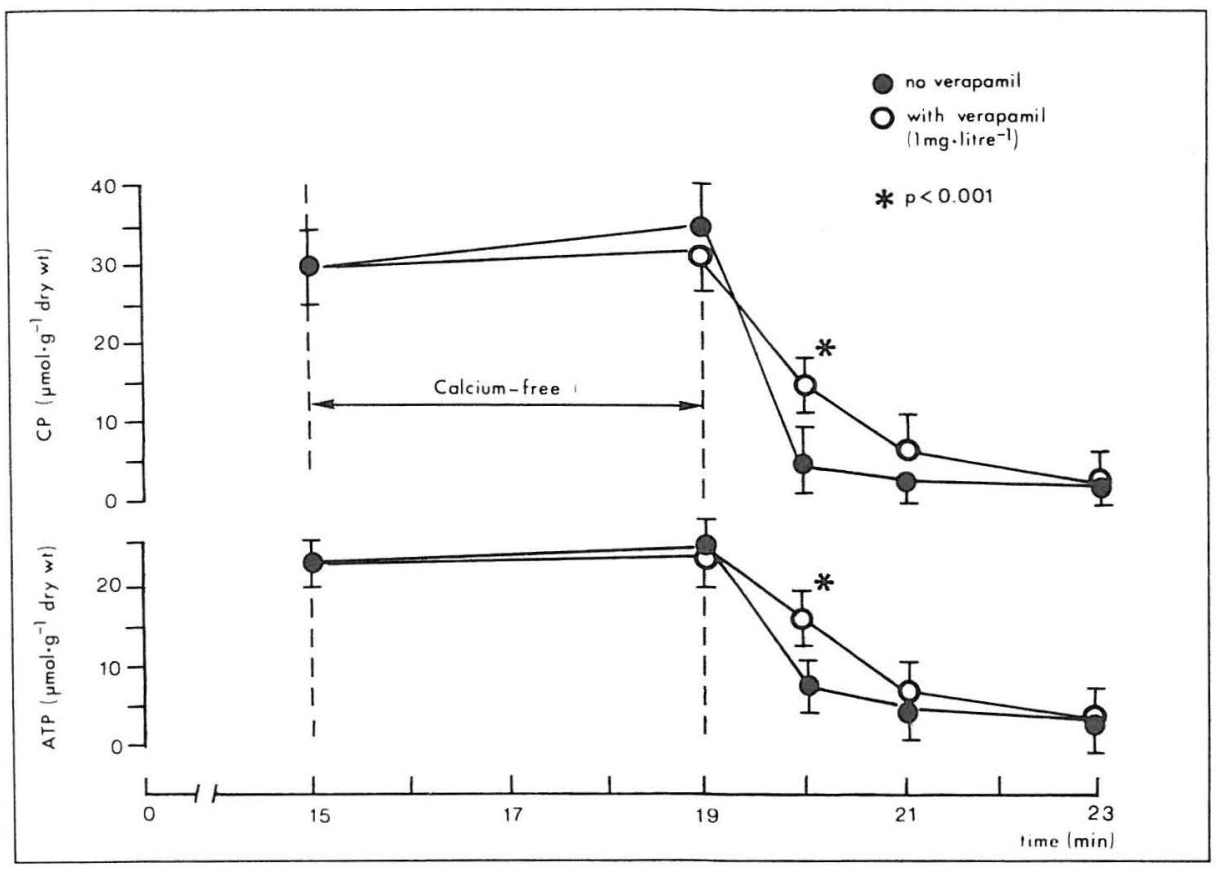

Figure 1: Effect of verapamil $\left(1 \mathrm{mg} \cdot \mathrm{l}^{-1}\right)$ on the depletion of myocardial CP and ATP stores, induced by reperfusion with calcium after a calcium-free period of 4 minutes. When verapamil was present, it was added to the calcium-free medium and the reperfusion medium. Values are given as mean $\pm \operatorname{SD}(n=4)$. Tests of significance relate to the significance of the difference between CP and ATP levels in hearts perfused in the presence and absence of verapamil. In certain cases, for the purpose of clarity, only one SD bar has been given. Reprinted with permission from The American Journal of Pathology 98, 769-790 (1980). 
Subsequent calcium-free perfusion for 4 minutes resulted in a slight increase in the endogenous stores of CP and ATP, irrespective of whether verapamil was present. During the first minute of reperfusion with calcium, myocardial CP fell from $35.6 \pm 2.9$ to $4.6 \pm 3.2 \mu \mathrm{mol} . \mathrm{g}^{-1}$ dry weight in the absence of verapamil, and from $33.1 \pm 2.6$ to $15.0 \pm 2.2 \mu \mathrm{mol} . \mathrm{g}^{-1} \mathrm{dry}$ weight in the presence of verapamil $(P<0.001)$. In the same period myocardial ATP fell from $20.8 \pm 1.4$ to $6.3 \pm 2.7 \mu \mathrm{mol} . \mathrm{g}^{-1}$ dry weight in the absence of verapamil, and from $20.6 \pm 1.5$ to $13.2 \pm 1.2 \mu \mathrm{mol} . \mathrm{g}^{-1} \mathrm{dry}$ weight in the presence of verapamil $(P<0.001)$. Figure 1 shows that although the rate of consumption of the tissue stores of ATP and CP during reperfusion was slower in the verapamil-treated than in the untreated hearts, after 4 minutes of reperfusion there was no difference between the ATP and CP content of treated and untreated hearts.

\section{Effect of verapamil on the ultrastructure during reperfusion}

At the end of the 15 minute stabilization period of perfusion with standard medium, the ultrastructure of the hearts was normal (Figure 2). Morphometric analysis showed that the mean sarcomere length amounted to $2.18 \mu$. After a subsequent calcium-free period of 4 minutes, followed by 30 seconds of reperfusion with calcium-containing solution, most cells showed contracted myofibrils and contraction bands (Figure 3). Many cells of the verapamil-treated hearts, however, contained relaxed myofibrils after the same perfusion sequence (Figure 4).

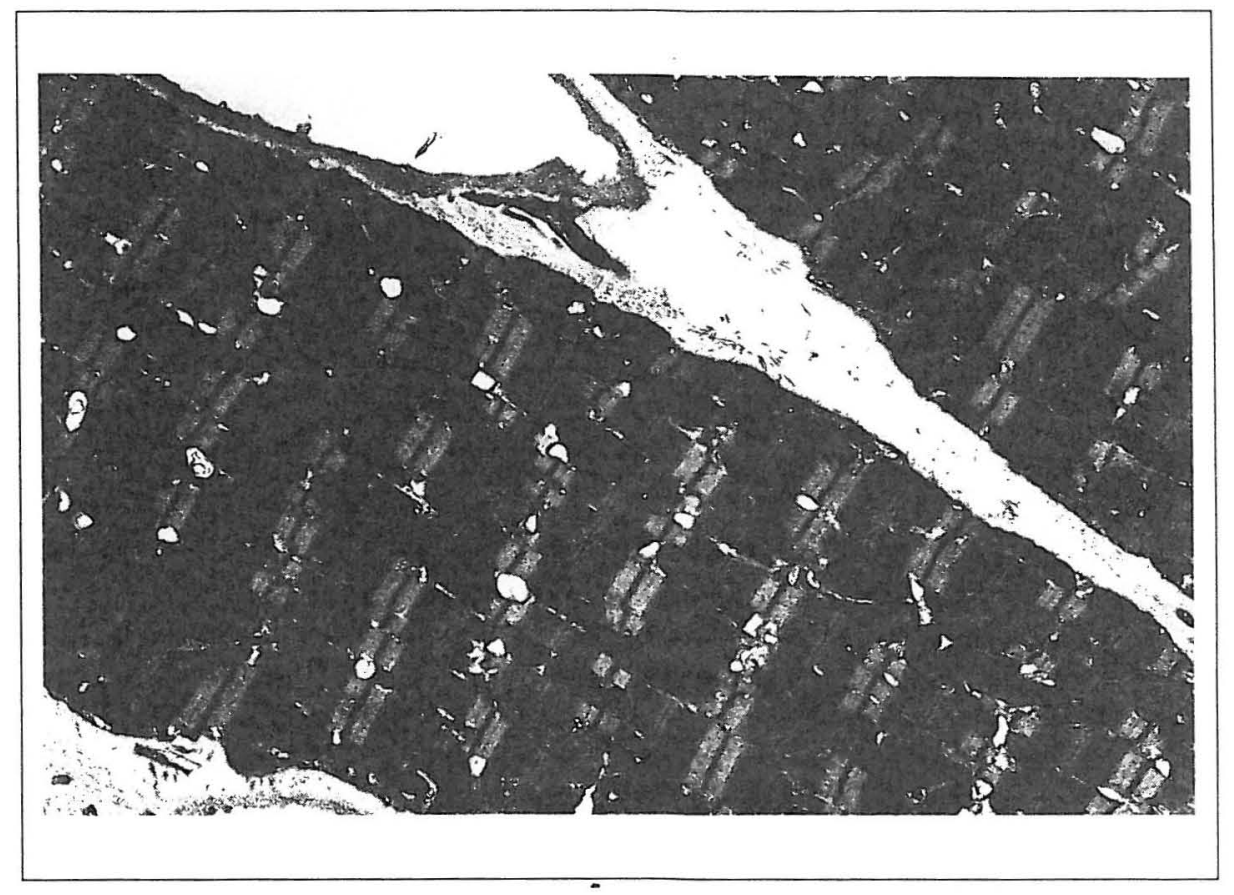

Figure 2: Control heart perfused for 15 minutes with standard medium. The heart has the appearance of normal myocardium. Myofibrils are in register and mitochondria have an electron-opaque matrix (x 7500). 


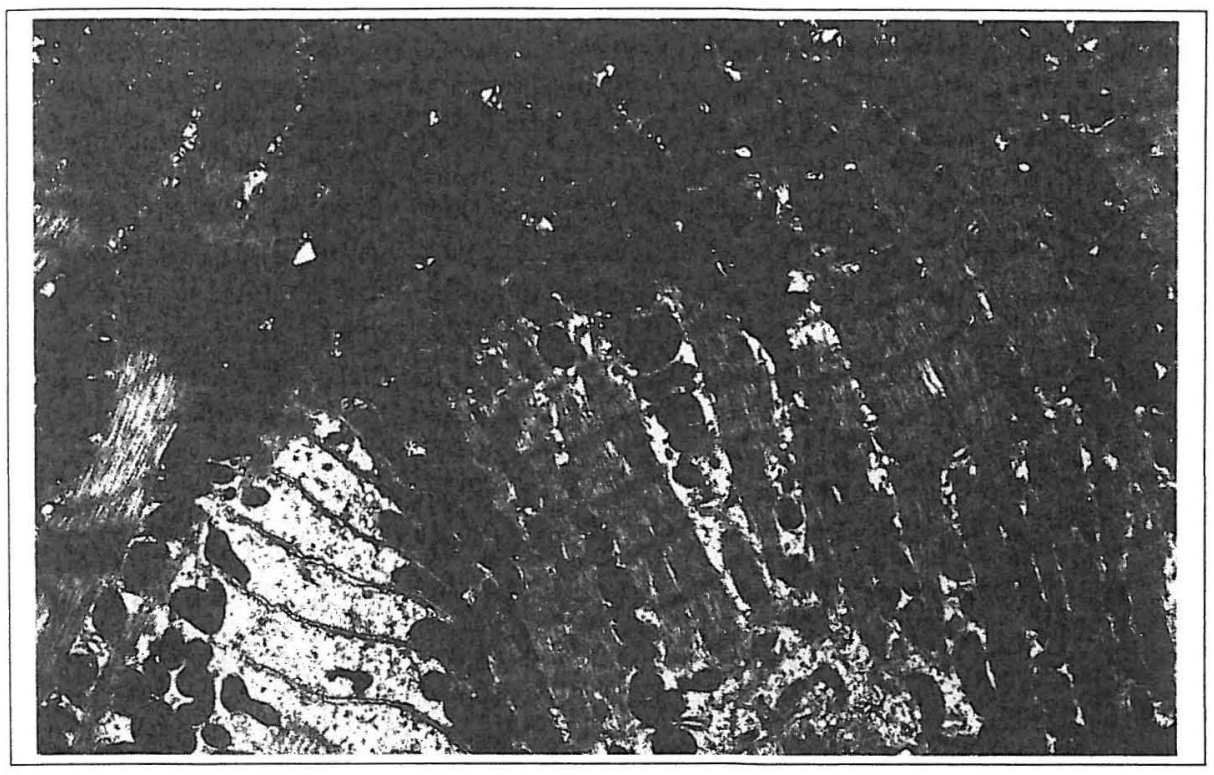

Figure 3: Heart perfused for 15 minutes with standard medium, followed by 4 minutes of calcium-free perfusion and 30 seconds of reperfusion with calcium-containing medium. This figure shows contracted myofibrils and contraction bands. The mitochondria have an electron-opaque matrix ( $x 7500)$.

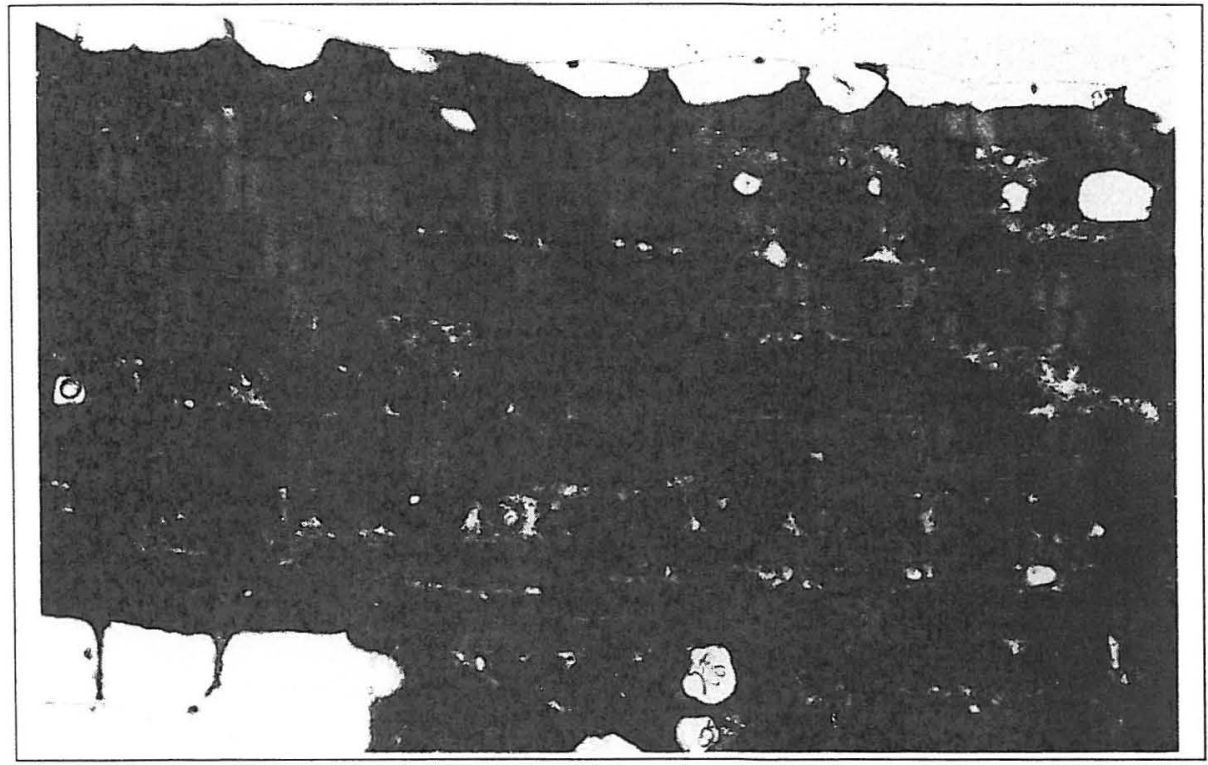

Figure 4: Heart perfused for 15 minutes with standard medium, followed by 4 minutes of calcium-free perfusion and 30 seconds of reperfusion with calcium-containing medium. The calcium-free medium and the reperfusion medium contained $1 \mathrm{mg} .1^{-1}$ verapamil. Myofibrils are relaxed and mitochondria have an electron-opaque matrix. This micrograph shows a separation of the basement membrane and formation of blebs (x 7500). 


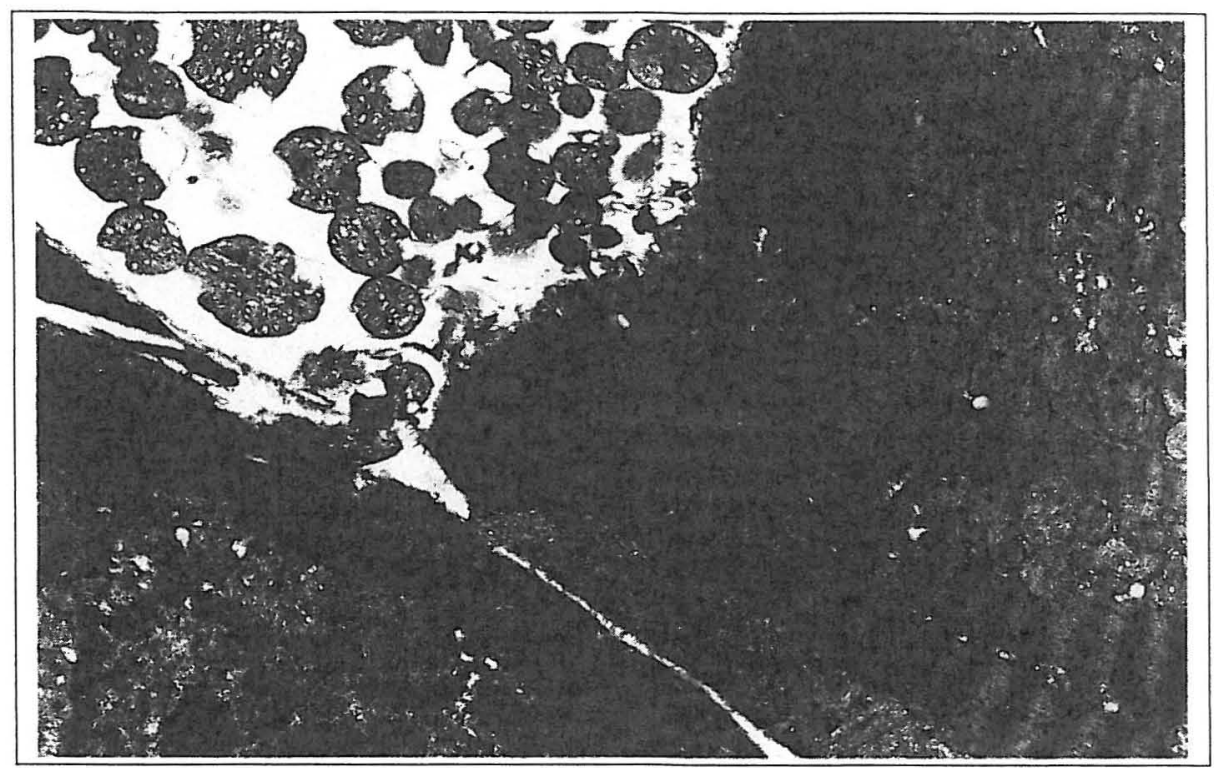

Figure 5: Heart perfused for 15 minutes with standard medium, followed by 4 minutes of calcium-free perfusion and 30 minutes of reperfusion with calcium-containing medium. Myofibrils are heavily contracted; mitochondria are swollen and contain electron-dense deposits ( $x 7500)$.

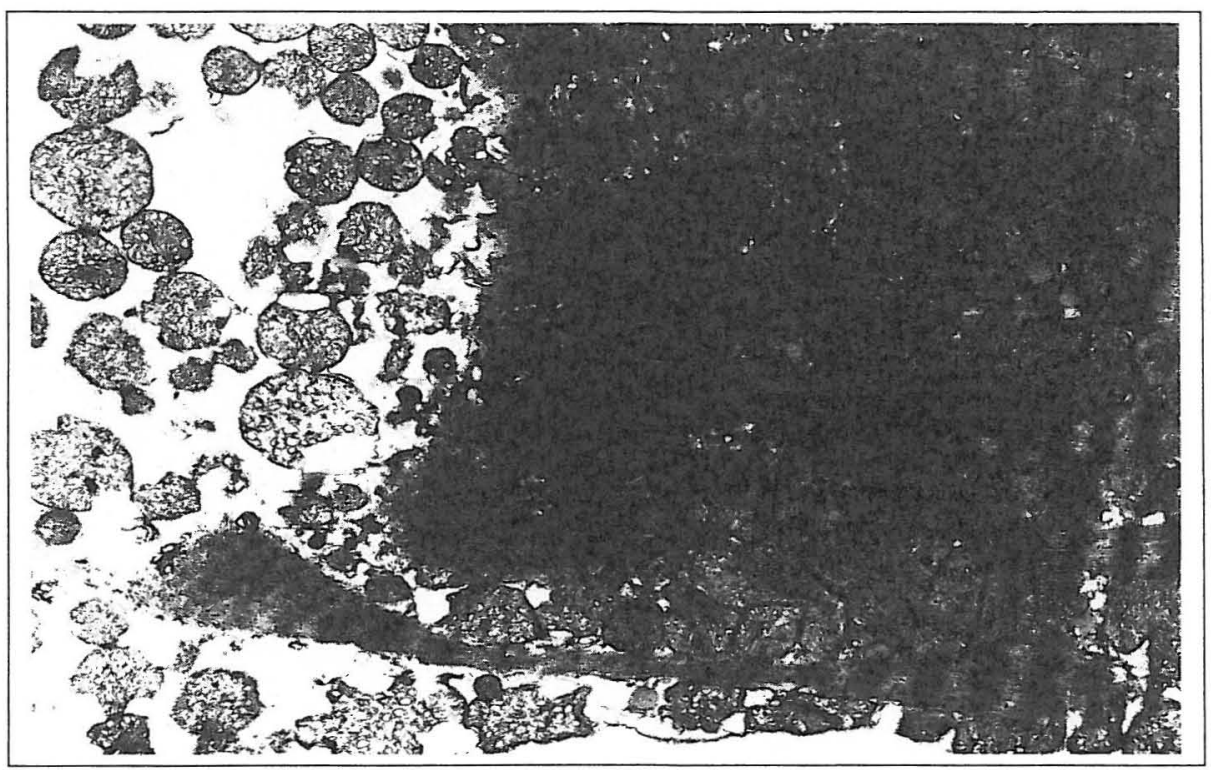

Figure 6: Heart perfused for 15 minutes with standard medium, followed by 4 minutes of calcium-free perfusion and 30 minutes of reperfusion with calcium-containing medium. The calcium-free medium and the reperfusion medium contained $1 \mathrm{mg} .1^{-1}$ verapamil. This cell shows severe contracture of the myofibrils. The mitochondria are swollen and contain electron-dense material (x 7500). 
The untreated series appeared to have a mean sarcomere length of $1.08 \mu$, whereas the verapamil-treated series had a mean sarcomere length of $1.33 \mu$. This difference was significant $(P<0.001)$. After 30 minutes of reperfusion with calcium-containing solution the hearts all showed evidence of extensive damage, irrespective of whether verapamil had been added (Figure 5 and 6 ). Every field showed gross tissue damage and severe contracture, and no quantitative analysis was undertaken.

\section{Discussion}

During calcium-free perfusion the myocardial cell membrane is altered in such a way that reperfusion with calcium-containing solution leads to a net gain in tissue calcium. The possible routes of calcium entry that occurs during the phase of calcium repletion have recently been reviewed (Grinwald and Nayler, 1981). These routes included the glycocalyx, the slow channels, the $\mathrm{Na}+-\mathrm{Ca}^{2+}$ and $\mathrm{K}+-\mathrm{Ca}^{2+}$ exchange mechanisms, passive diffusion, and abnormal sites of calcium entry (e.g. damaged areas of the intercalated discs, and distorted ion selective channels). The present results (Table 1) show that under our experimental conditions the calcium entry blockers verapamil, nifedipine, diltiazem and lidoflazine did not reduce the massive enzyme release, which is one of the characteristics of the calcium paradox. Moreover, Alto and Dhalla (1979) and Nayler and Grinwald (1981) demonstrated that verapamil and D600 did not prevent the massive gain in calcium that occurs during the calcium paradox.

Our enzyme release data contrast with the results of Hearse and co-workers (Hearse, Baker and Humphrey, 1980; Hearse and Baker, 1981; Baker and Hearse, 1981), who reported that the calcium entry blockers nifedipine, verapamil, D600, diltiazem, terodiline and fendiline were able to reduce protein leakage by up to one third. There is growing evidence that calcium entry blockers may be protective in a submaximal or mild form of the calcium paradox. Van Belle et al. (1982) demonstrated that lidoflazine had a protective effect in a submaximal calcium paradox, which was induced by successive perfusion with $15 \mu \mathrm{mol} . .^{-1}$ calcium for 5 minutes, and reperfusion with 1.25 mmol ..$^{-1}$ calcium. Ohhara, Kanaide and Nakamura (1982) investigated the effect of verapamil on severe and mild forms of the calcium paradox. Verapamil did not influence the severe calcium paradox, but had a marked protective effect on the mild calcium paradox. The mild paradox was produced by reducing the coronary flow rate during the calcium-free period. These findings may be of interest for cardiac surgery where cold calcium-free cardioplegic solutions are widely used to induce cardiac arrest. It has been claimed (Tyers, 1975; Jynge, Hearse and Braimbridge, 1977) that the use of these solutions may adversely affect membrane permeability and integrity, and may predispose the heart to some form of the calcium paradox. It is worth noting that Ashraf et al. (1982) found a complete inhibition of the calcium paradox injury by a combination of diltiazem treatment and hypothermia.

Although our results show that calcium entry blockers do not protect rat hearts against the severe form of the calcium paradox, the time course of the events that occur during the development of the paradox may be altered. Verapamil had an energy-sparing effect (Figure 1) and reduced the decrease of the mean sarcomere length (Figures 3 and 4) during the first few minutes of reperfusion. A reduction of the rate of calcium entry during the early phase of calcium repletion may be responsible for these effects. 


\section{Acknowledgment}

The authors are grateful to $\mathrm{Dr}$. C. Borst for his constructive criticism.

\section{References}

Alto, L.E. and Dhalla, N.S. Myocardial cation contents during induction of calcium paradox. Am. J. Physiol. 237, H713 (1979).

Ashraf, M., Onda, M., Benedict, J.B. and Millard, R.W. Prevention of calcium paradox-related myocardial cell injury with diltiazem, a calcium channel blocking agent. Am. J. Cardiol., 49, 1675 (1982).

Baker, J.E. and Hearse, D.J. A comparison of the ability of slow channel calcium blockers to reduce tissue damage during the calcium paradox in the rat heart. J. Mol. Cell. Cardioi., 13 (Suppl. 1), 6 (1981).

Boink, A.B.T.J., Ruigrok, T.J.C., Maas, A.H.J. and Zimmerman, A.N.E. Changes in high-energy phosphate compounds of isolated rat hearts during $\mathrm{Ca}^{2+}$-free perfusion and reperfusion with $\mathrm{Ca}^{2+}$. J. Mol. Cell. Cardiol., 8, 973 (1976).

Boink, A.B.T.J., Ruigrok, T.J.C., De Moes, D., Maas, A.H.J. and Zimmerman, A.N.E. The effect of hypothermia on the occurrence of the calcium paradox. Pfluegers Arch., 385, 105 (1980).

Frank, J.S., Langer, G.A., Nudd, L.M. and Seraydarian, K. The myocardial cell surface, its histochemistry, and the effect of sialic acid and calcium removal on its structure and cellular ionic exchange. Circ. Res., 41, 702 (1977).

Grinwald, P.M. and Nayler, W.G. Calcium entry in the calcium paradox. J. Mol. Cell. Cardiol., 13, 867 (1981).

Hearse, D.J. and Baker, J.E. Verapamil and the calcium paradox: a reaffirmation. J. Mol. Cell. Cardiol., 13. 1087 (1981).

Hearse, D.J., Baker, J.E. and Humphrey, S.M. Verapamil and the calcium paradox. J. Mol. Cell. Cardiol., 12, 733 (1980).

Hearse, D.J., Humphrey, S.M., Boink, A.B.T.J. and Ruigrok, T.J.C. The calcium paradox: metabolic, electrophysiological, contractile and ultrastructural characteristics in four species. Eur. J. Cardiol., 7, 241 (1978).

Jynge, P., Hearse, D.J. and Braimbridge, M.V. Myocardial protection during ischemic cardiac arrest; a possible hazard with calcium-free cardioplegic infusates. J. Thorac. Cardiovasc. Surg., 73, 846 (1977).

Langendorff, O. Untersuchungen am überlebenden Säugetierherzen. Pfluegers Arch., 61, 291 (1895).

Mines, G.R. On functional analysis by the action of electrolytes. J. Physiol. (London), 46, 188 (1913).

Nayler, W.G. and Grinwald, P.M. The effect of verapamil on calcium accumulation during the calcium paradox. J. Mol. Cell. Cardiol., 13, 435 (1981).

Ohhara, $H$., Kanaide, $H$. and Nakamura, M. A protective effect of verapamil on the calcium paradox in the isolated perfused rat heart. J. Mol. Cell. Cardiol., 14, 13 (1982).

Ruigrok, T.J.C., Boink, A.B.T.J., Slade, A., Zimmerman, A.N.E., Meijler, F.L. and Nayler, W.G. The effect of verapamil on the calcium paradox. Am. J. Pathol., 98, 769 (1980).

Tyers, G.F.O. Metabolic arrest of the heart. Ann. Thorac. Surg., 20, 91 (1975).

Van Belle, H., Xhonneux, R., Borgers, M. and Flameng, W. Cardioprotective effect of adenosine, lidoflazine and R 51 469. International Symposium on Adenosine, Charlottesville (USA) (1982).

Zimmerman, A.N.E. and Hülsmann, W.C. Paradoxical influence of calcium ions on the permeability of the cell mem. branes of the isolated rat heart. Nature (London). 211, 646 (1966)

Zimmerman, A.N.E., Daems, W., Hülsmann, W.C., Snijder, J., Wisse, E. and Durrer. D. Morphological changes of heart muscle caused by successive perfusion with calcium-free and calcium-containing solutions (calcium paradox). Cardiovasc. Res., 1, 201 (1967). 